\title{
Higher Technical and Vocational Education and Training Programmes and Its Impact on the Libyan Manufacturing Industry
}

\author{
Nuri M. Triki \\ Rigdaleen-Higher Institute for Applied Engineering, Libya
}

\begin{abstract}
Rapid developments in technology and manufacturing industry have made many occupations and trades, such as turners, machinists and grinders, and draftsmen-obsolete, while others need to be modified. Manufacturing industry in Libya has suffered from a shortage of skilled and semi-skilled manpower. In the 1990s, a network of Higher Technical and Vocational Education and Training (TVET) colleges was introduced in Libya to enhance the supply of skilled manpower. This paper presents initial results from a survey of students at TVET colleges. It explores their perception regarding TVET programmes as well as workrelated issues in Libya. The main aim of this research is to investigate the current skills gaps in manufacturing sector. To achieve this goal a questionnaire has been designed, and distributed to students at higher education to explore their views in this regard. The study indicated a direct relationship between the needs of the industrial sector and technical disciplines, where education is the output of the most important technical inputs to the manufacturing industry. The results also indicated how to improve technical programmes which will help serve the community by providing students with adequate technical information.
\end{abstract}

\section{Introduction}

As all developing countries, Libya has paid more attention to the administration reform of the TVET during the past ten years or so. For example, the Libyan government has established many new TVET institutions, reviewed organisational structures of existing institutions and sent abroad many people in order to gain skills and knowledge [7, 8]. To this effect, Libya has considered TVET as one of the most important factors leading towards the solution of the nation's shortage of skilled workers in many sectors and in particular the manufacturing sector and its important role in economic and industrial development cannot be easily ignored [9]. Therefore, it is also part of the formal education system and the main aims are to provide students with certain basic skills and knowledge and to supply them with the necessary tools to increase and update their knowledge through the life-long education process, as well as to deliver and support the Libyan industrial sector with the skilled and knowledgeable technicians [8].
The number of colleges increased from 54 in $1995 / 96$ to a country-wide network of 84 TVET in 2000 with a growth rate of 55.5 percent [12], and by the year 2004 the number of TVET institutions has increased to more than 120 institutes- an increase of 70 percent [7]. TVET are post-secondary institutions and provide theoretical and practical curriculum [3]. In Libya the manufacturing industry has suffered a shortage of skilled and semi-skilled manpower [1] [13]. This problem has become more marked over the past decades, the country has tried to keep pace with technological changes that affect many developing countries [8]. To address this critical problem, a network for TVET institutions was introduced in the 1990s to enhance and improve the provision of the necessary highly skilled workforce needed for national socio-economic development plans and in particular manufacturing industry [10]. Studies conducted by [1][2][9][13] on Libyan Higher Education (HE) and TVET have provided evidence that HE and TVET graduates do not match the demands of the manufacturing sector. Therefore, it is well realised that Libya as a developing country needs more trained manpower in the areas of engineering and technology, to continue to train and produce a significant number of graduates in the fields of engineering and technology.

\section{Relationship with Industry}

Providers of TVET should use a wide range of methods including joint venture with industry and summer courses to linking between the learning and industry. Successful partnerships between TVET providers and industry are essential to the national economy [17]. According to [5], the purpose of working with industry is to develop the TVET curriculum. Authors in [11] stated that a good relationship between the university and industry facilitates the placement of students for training and provide case studies for enriching the delivery of the curriculum. Some type of industry supervision should be offered by the training place, while university staff may pay visits to follow the progress of students during their time in the industry. [6] argue that the development of the graduate engineer cannot be a classroom based experience; rather it requires the specific involvement and commitment of industry to be involved with engineering programs. One of the strategies in order to achieve this is through the development of partnerships between industry and education. TVET linkages with industry can clearly involve a wide range of mechanisms and 
activities, from providing national policy direction and identifying skill needs, to setting skill standards and providing technical input into teaching and learning resources [6]. However, TVET policy design and delivery should be achieved through a new partnership between government, employers, professional associations, industry, and employees [20, p. 13]. [14] [19], pointed out, in order to make the best use of resources and provide high quality TVET for students, it is essential that the TVET system and the market place work together clearly. This collaboration should include the directing of resources towards occupational and career preparation where there is the greatest need and opportunity. [5], stated that industry partners believed that the strength of their relationships with training institutions is central to creating skills and knowledge for solution of the problems.

\section{Methodology}

The data used in this study were based on a survey data of nine higher education institutions (Universities/ Institutions) and manufacturing industry in Libya. ). In order to fulfil the objectives of this study, quantitative data using a questionnaire was created for the purpose of obtaining information to examine phenomenon under investigation. The questionnaire aimed to elicit the students' perception of the skills and knowledge they are acquiring during their study at the engineering departments in different Libyan Higher Education Institutions (HEIs), and the engineers and technicians working in manufacturing industry about the education and training they received before joining the organisation. The questionnaire was administrated to students in the above mentioned nine HEIs (universities/ institutions) and engineers and technicians in manufacturing industry. Analysis of the questionnaire assisted with collecting students and engineers perceptions of the effectiveness of each stage of the instructional design process. The questionnaire used a six-point Likert scale style format. This format allows the students and engineers to place themselves on an attitude continuum for each statement-running from 'Strongly Disagree', 'Disagree', 'Slightly Disagree', 'Slightly Agree', 'Agree', 'Strongly Agree' [16]. The sample size was 625 and 137 for students and engineers respectively, and this represented a high response rate $(85 \%$ for students and $61 \%$ for engineers). The results of partnership with industry was analysed and are presented in this paper.

\section{Results and Discussion}

\section{Partnership with Industry - Students' Perception}

\section{(Q1). Linkage of course studied to the relevant industry}

Students were asked whether the course they study is well linked to the relevant industry (Q.1). Only a minority of $17.7 \%$ of the students involved agreed that their course is linked to the relevant industry. In contrast, $45.0 \%$ of them disagreed, and more than one-third of them (37.5\%) either slightly agreed or slightly disagreed. This clearly indicates that the curriculum delivered is not well designed and that there is a rather poor link between course design by the higher education institutions and the relevant industry. However, this also substantiates the major concern that a relatively large number of students were not decisive, possibly these students have not decided to study engineering as their personal interest. This pattern is in agreement with the literature concerning the Libyan education system which reported that the Libyan education system is not providing the skills required to drive the economy forward [18]. The pattern of responses also reveals the poor quality of curricula, teachers and infrastructure and recent literature maintains that curricula must be designed to match the needs of students and cater for their aspirations and requirements [15].

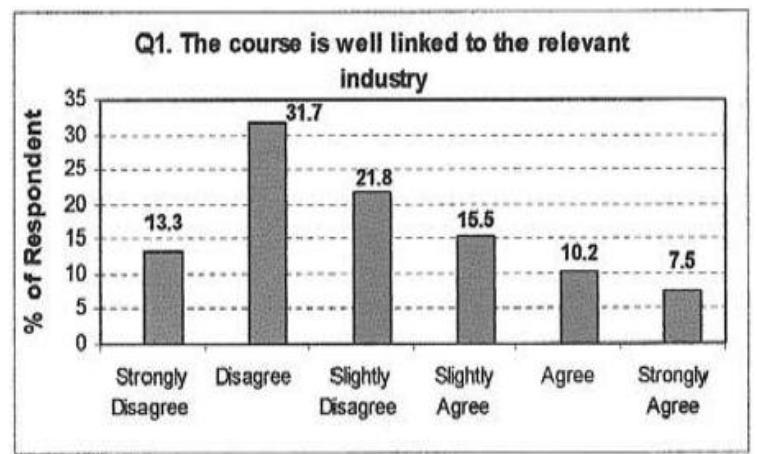

Figure 1: Students' perception of linkage between courses studied and relevant industry

\section{(Q2). Lectures presenting case studies from industry}

Students also asked whether lectures delivered to them present case studies from industry (Q.2). While $28.7 \%$ of the respondent students agreed that lectures delivered during the delivery of the course to them present case studies, $43.4 \%$ of them disagreed and more than one-quarter of them $(27.9 \%)$ were undecided. This pattern of responses might suggest that more lectures have not presented case studies from relevant industries. This pattern also clearly 
demonstrates the poor or inadequate practical application of theory and the poor design of the curriculum. Furthermore, it demonstrates the poor linkage between higher education institutions and the relevant industry which will recruit these students when they graduate. This raises the concern that higher education institutions need to liaise with the industry to help design and deliver an adequate curriculum that helps students in their future career.

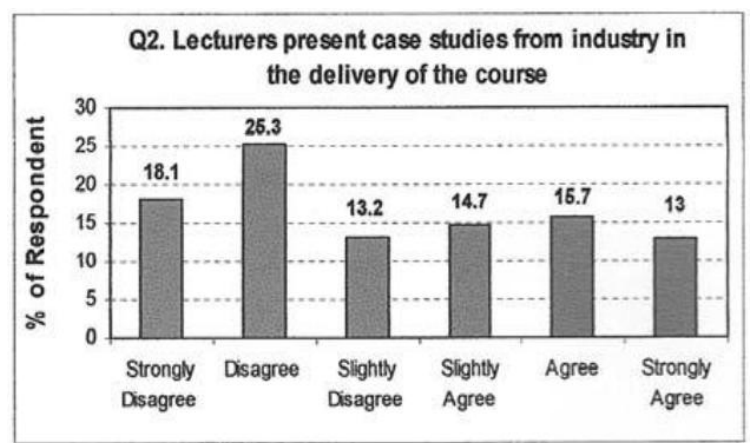

Figure 2: Students' perception of lectures presenting case study from industry

\section{(Q3). Visiting industrial sites relevant to their Study}

When asked whether they enjoy visiting industrial sites that are relevant to their study (Q.3), more than half of respondent students indicated their agreement with this issue, in contrast to around onequarter of them $(25.6 \%)$ who indicated that they did not enjoy visiting such sites. A minority of $16.0 \%$ of students were either slightly agreeing or slightly disagreeing. On the whole, it can be said that most students enjoyed such visits, possibly they felt that such visits would give them an idea of the nature and type of work carried out in these sites, and also give them some practical insight of the job that they might have after graduation. Such visits would increase students' knowledge and can prepare them for their future career.

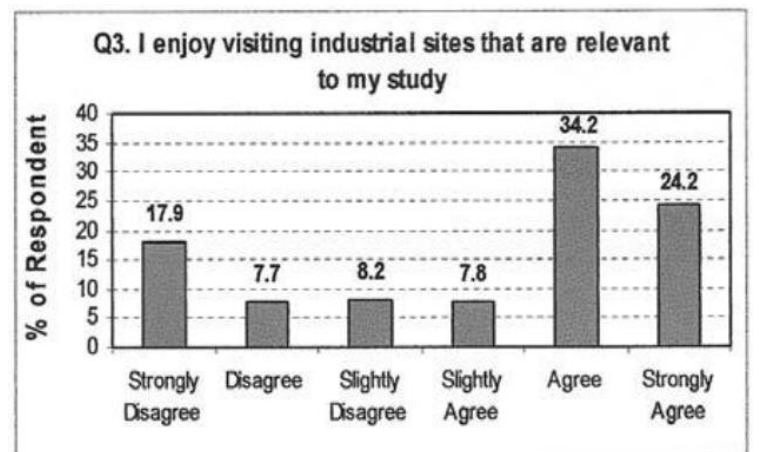

Figure 3: Students' perception of visiting industrial sites relevant to their study

\section{(Q4). Students' training in relevant industry as} part of their study

Students were also asked whether they like to spend time on training in relevant industry to their study (Q.4), most of the respondent students (71.2\% of the sample) indicated their agreement with this item, in contrast to a minority of $11.0 \%$ of them who disagreed with this statement and $18.5 \%$ of them who were either slightly agreeing or slightly disagreeing with this statement. Overall, the majority agreed with this issue. Spending time on training in relevant industry is very important for engineering students in order to see at hand how they are expected to do their jobs after graduation and recruitment by the industry.

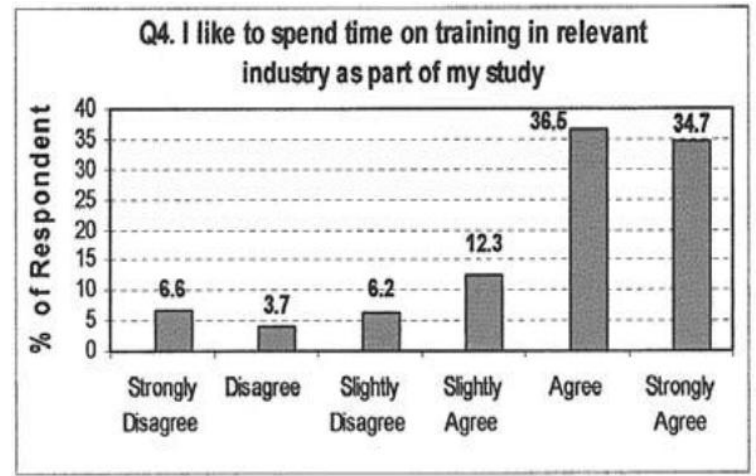

Figure 4: Students' perception of their training in industry as part of their study

Partnership with Higher Education and Vocation Training Institutions Engineers' and Technicians' Perception

(Q5). TVET institutions' role in updating and enhancing their skills

Engineers and technicians were asked whether TVET institutions play a key role in updating and enhancing their skills (Q.5). About $40.0 \%$ of respondents agreed that TVET institutions play a key role in updating and enhancing their skills, whereas many of them (37.8\% of the sample) slightly agreed or slightly disagreed. Around $20.0 \%$ of these indicated their disagreement with the statement. Overall, more than half of them agreed. This pattern is more in agreement more than disagreement, since those with a Bachelor Degree are expected to have graduated from universities as engineers whereas most of the other group has attended TVET colleges. 


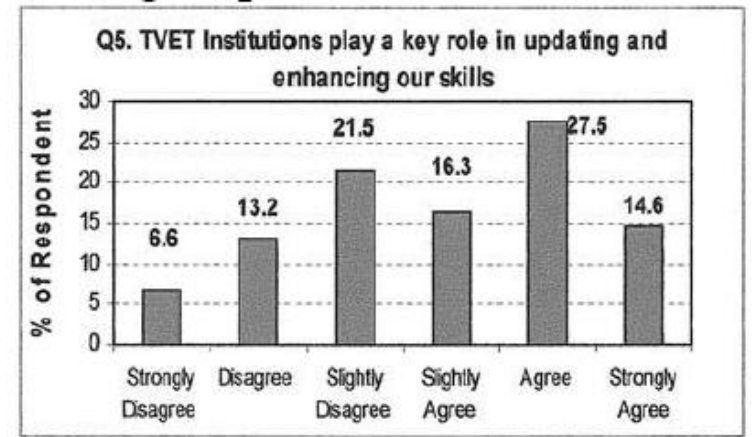

Figure 5: Engineers' perception about the TVET institutions play a role in updating their skills

\section{(Q6). Hosting engineering and technical students in organizations}

In response to (Q.6), whether hosting engineering and technician students in organisations will prepare them better for their future professional career, most engineers and technicians $(69.4 \%)$ agreed that placing students at their organizations will prepare them better for their professional career, and only an insignificant minority (5.8\%) disagreed, and $24.8 \%$ of them slightly agreed or slightly disagreed. This pattern of responses might be due to engineers and technicians' experience and perception of the usefulness of industrial placement for acquiring employability skills. Industrial placement will help students to acquire further knowledge and skills relating to the nature of their future jobs and would become more productive and more efficient in carrying out their jobs after graduation and recruitment.

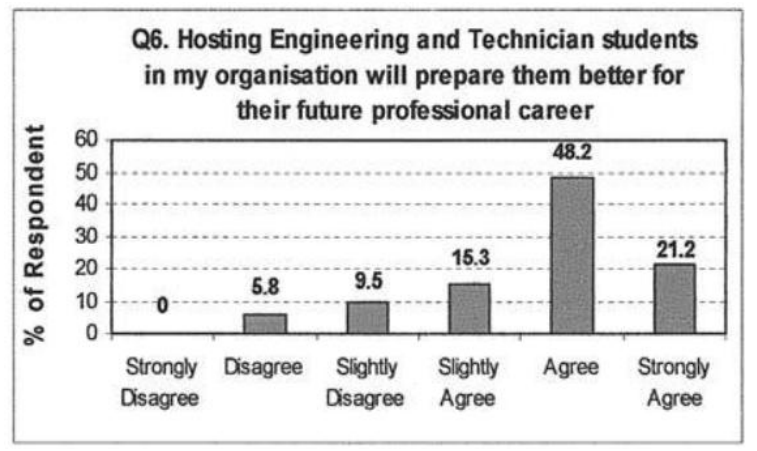

Figure 6: Engineers' perception of hosting engineering and technician students in organization

\section{(Q7). Consultation with TVET institutions}

When engineers and technicians were asked whether they consult TVET institutions to solve technical problem, develop new product or to enhance performance (Q.7), most engineers and technician $(56.2 \%$ of the sample) disagreed that they do so, in contrast to $22.6 \%$ of them who agreed, and $21.1 \%$ who either slightly disagree $(10.9 \%)$ and slightly agree (10.2\%). Overall, it can be said that more than two-thirds of engineers and technicians disagreed with this statement. This pattern of responses clearly reveals the poor linkage between TVET institutions and the relevant industry.

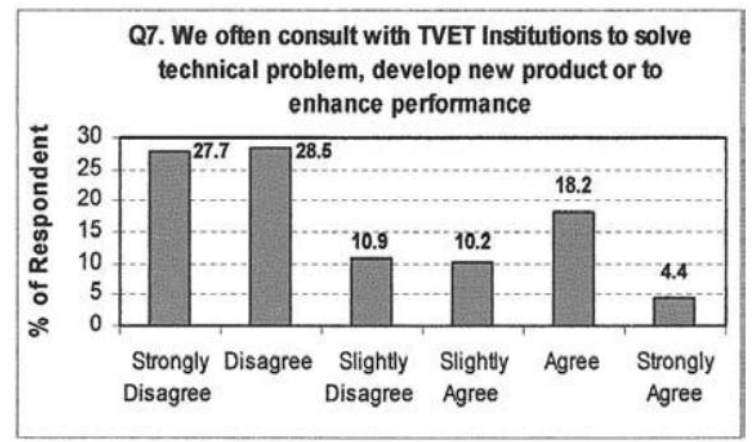

Figure 7: Engineers' perception of consulting with TVET institutions

\section{(Q8). Keeping contact with college/university after graduation}

Engineers and technicians were asked whether they have kept their contacts with their college or university after their graduation (Q.8). The majority of respondents $(70.1 \%$ of the sample) disagreed with the statement, indicating that they have no contacts after graduation; only $10.9 \%$ of them agreed that they have kept contacts after graduation and 18.9\% of them either slightly disagree $(13.1 \%)$ or slightly agree $(5.8 \%)$. Overall, it can be said that the majority of respondents (including those slightly disagreeing) have not contacted their colleges or universities since graduation. This pattern of response may also tie up somewhat with the pattern of responses to (Q.7) above, and also indicates the poor linkage between TVET institutions and industry. This pattern of response, however, is not surprising in Libya, as is the case in most Arab universities and colleges, in which higher education institutions do not run programmes such as 'alumni' programme, as is the case in the UK, hence, contacts stopped as soon as the students graduate and nothing is known about them by their colleges and universities.

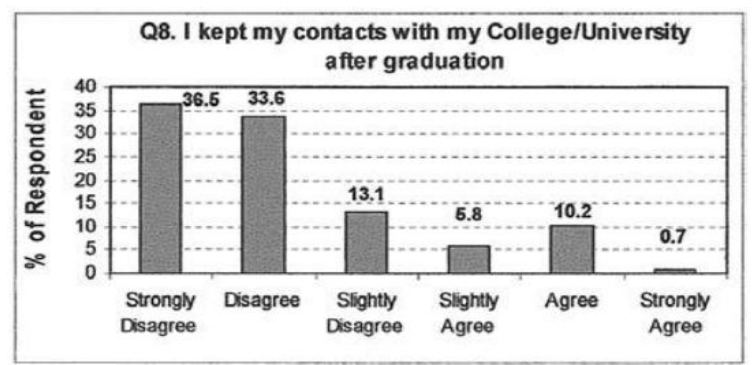

Figure 8: Engineers' perception of their contact with TVET college/university after graduation 


\section{(Q9). Placement of lecturers in manufacturing organisations}

When asked whether placing lecturers in manufacturing organisations will improve their awareness of employers' requirements (Q.9), the majority of respondents agreed with the statement; only a small minority (9.4\%) disagreed and $18.9 \%$ either slightly agree $(10.9 \%)$ or slightly disagree $(8.0 \%)$. Placing academic staff in manufacturing organization will provide them with the opportunity to see at hand what these organisations make or produce and what sort of engineers and technicians are required by them so that they can suggest to their institutions of the programmes needed that would help improve the design and delivery of curricula to make more geared to the requirements of these organisation and supply them with staff that can succeed in their jobs. This will also help strengthen the ties and linkages between higher education institutions and the manufacturing organisations.

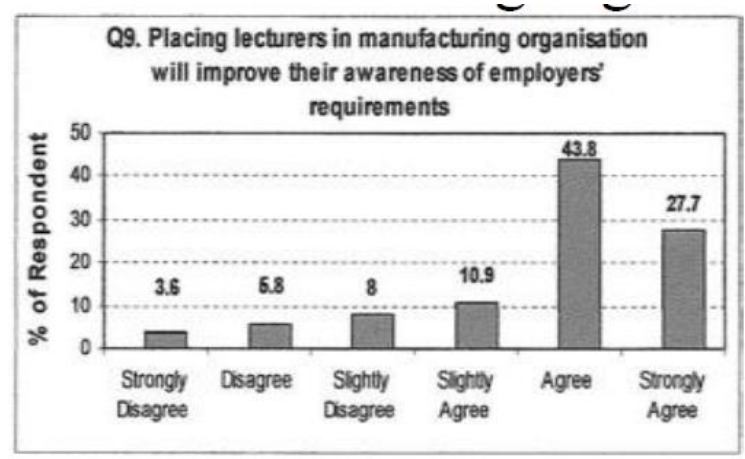

Figure 9: Engineers' perception of placing lecturers in manufacturing organization

\section{(Q10). Studying for a higher qualification if an opportunity arises}

Finally, when asked whether they will go back to college or university to study for a higher degree should an opportunity arise (Q.10), more than half of respondent engineers and technicians $(54.7 \%)$ agreed that they will do so; only (16.7\%) of them disagreed, and $28.4 \%$ of them either slightly agree $(10.9 \%)$ or slightly disagree $(17.5 \%)$. This pattern of responses indicates that most of the respondents want to pursue their studies if they have the chance to do so. Those agreeing with the statement are motivated individuals who want to improve and further their career by obtaining higher qualifications that help their promotion within their organisations.

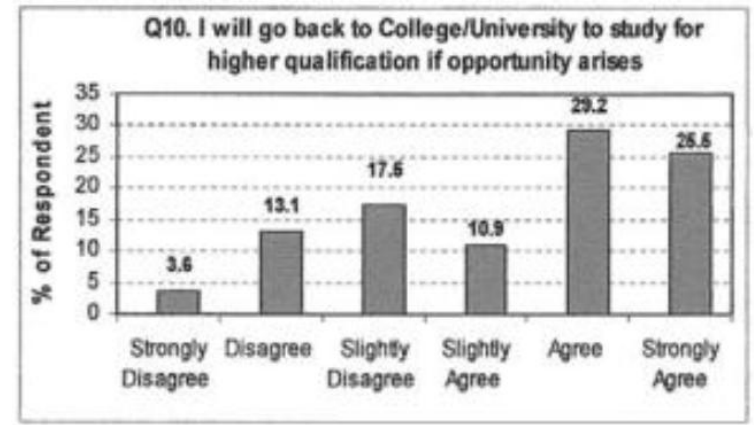

Figure 10: Engineers' perception of studying for higher qualification if an opportunity arises

\section{Conclusion}

In summary, with a global economy that interconnects every country around the world, the demand for qualified experts' increases. Attracting students into and graduating students from engineering degree programmes is a growing challenge. Evidence is emerging that competencebased teaching, combined with a strong connection to manufacturing sectors, can positively impact student academic outcomes. One of the missions of universities and TVET institutions are to guide and encourage students' qualified integration. Consequently, higher education programmes should prepare students and train mature workers according to the manufacturing industry demands and technological evolution, focusing teaching on competences, in order to face the economic and social challenges ahead. On the other hand, the involvement of enterprises and industry is crucial and should be made in different aspects: curricula design; interchange of students, organisation of study visits and bringing professional to schools; quality assessment and regular feedback.

Notwithstanding that the TVET institutions have increased substantially during the last ten years or so, there are still some problems in the system that affects their performance. TVET institutions, considered by the government as the main supplier of highly skilled manpower, have been unable to produce the required graduates both in quality and quantity. In fact, many of these TVET institutions suffered from the shortage in physical and human resources that are essentially required for this type of educational institutions. All these issues hampered TVET from performing their required functions in society in general and the manufacturing industry in particular. Furthermore, it can be concluded from the findings and discussions above that TVET institutions in Libya is based on a weak foundation and that TVET education is still out of step with changes that have taken place in the national economy. This weakness should be remedied so that courses given at HEIs are linked positively with the industry. This weak linkage may reflect on poor 
coordination between the various sectors of industry and HEIs. This weak linkage is also substantiated by the fact that the majority of students are not presented with case studies from the relevant industry. It can therefore be concluded that theory is not put into practice. However, it can also be concluded that students enjoyed their field trips to industrial site, and most of them spent some time on training in relevant industry as part of their study. This can be seen as an attempt by the educational institutions to put theory into practice.

From the engineers' and technicians' perspectives, it can be concluded that TVET institutions played a role in updating and enhancing their skills and placing engineering and technician students in organisations help prepare them for future work. It can also be concluded that consultation with TVET institutions to resolve technical problems is not up to the required standard; this substantiates the poor linkages between TVET institutions and the relevant industries.

This poor linkage is further substantiated by the fact that most participants did not keep contacts with their educational institutions after graduation. Placing lecturers in manufacturing organisation was perceived to improve their awareness of the employers' requirements. It can also be concluded that many respondents wanted to study further should the opportunity to do so becomes accessible.

\section{References}

[1] Abdul-Hadi, S. (2007), The Adequacy of University Education outputs of the Libyan Labor Market Requirements, unpublished thesis, Faculty of Arts and Education, Al-Tahady University, Sirte.

[2] Albadri, A. (2007), Some Problems of Higher Education Policies. Paper presented in the first national Conference on Public Polices in Libya. Garyounis University, Benghazi, Libya 12-14 June 2007, 30 pages (In Arabic).

[3] Aldhaif, R. M., Murad, O. H. and Saaod, A. E. (2001), Higher Engineering Colleges between Reality and Targets, In Proceedings of the Conference on the Development of Engineering and Technical Education in the Beginning of Twenty First Century, Hoon, 30-31/10/2001, 20 pages (In Arabic).

[4] Al-Jumaily, A. and Stonyer, H. (2000), Beyond Teaching and Research: Changing Engineering Academic Work. Global Journal of Engineering Education, Vol.4, No. PP. 89-98.

[5] Callan, V., and Ashworth, P. (2004). Working Together: Industry and VET Provider Training Partnerships. National Centre for Vocational Education Research, Adelaide.

[6] Comyn, P. (2007), Industry Links with Vocational Education and Training in China. [Online]
http://www.avetra.org.au/publications/journals/Vol5_2\%2 $0 \% 202007 \% 20 \% 20$ Backup $\% 0$ of $\% 20$ Comyn $\% 20$ accessed on $20 / 12 / 2012$.

[7] El-Hawat, A., Saeed, B. and Alawami, M. (2005), Higher education in Libya: achievements and aspirations, 1st edition. Tripoli: Publications of the Libyan National Committee for Education, Culture and Science Association, and university faculty members in Libya (In Arabic).

[8] El-Hawat, A. (2003), Libya. In: Teferra, D and Altbach, Ph G (eds.) "African Higher Education: An International Reference", Handbook. Indiana: Indiana University Press.

[9] El-Magouri, A. R. (2005), Relationship between Higher Education Outputs and Labour Market: Reality and Development Potentialities, Al-Jameai, Vol. 9, pp. 71-96 (In Arabic).

[10. Elzalitni, S. and Lees, M. (2007), Higher College Students' Perception of Vocational Education and Training Programmes in Libya. Presented at Salford Postgraduate Annual Research Conference, 10-11 May 2007, Salford University, UK.

[11] El-Raghy, S. (1999), Quality Engineering Education: Student Skills and Experiences. Global Journal of Engineering Education, Vol. 3, No.1, PP. 25-30.

[12] GDHVECs, (The General Directorate of Higher Vocational Education Colleges) (2000), A report on the public higher vocational education and training colleges, the Secretariat of Education, unpublished document (In Arabic).

[13] Keibah, M. S. (1998), Higher Education and Labour Market in Libya, Journal of Economic Research, 9: 179202, (In Arabic).

[14] Lynch, R. (2000), High School Career and Technical Education for the First Decade of

the 21st Century. Journal of Vocational Education Research, 25 (2).

[15] Mbajiorgu, N., and Reid, N. (2006), Factors Influencing Curriculum Development in Chemistry. Published by the Higher Education Academy Physical Sciences Centre. [Online] http://www.physsci.heacademy.ac.uk accessed on 2/9/2012.

[16] Oppenheim, A. N. (1992), Questionnaire design and attitudes measurement. London: Printer Publishers.

[19] Pagtakhan, R. and Rock, A. (2002), UniversityIndustry Partnerships Driving Innovation. [Online] http://www.nserc.gc.ca/news/2002/p021028.htm accessed on $29 / 10 / 2012$.

[18] Porter, M. and Yergin, D. (2006), National Economic Strategy: An Assessment of the Competitiveness of the Libyan Arab Jamahiriya. Cambridge: Monitor Group, Cambridge Energy Research Associates (CERA). [Online] 
http://www.transparency-

libya.com/index.php?option=com_content\&task=view\&id $=296 \&$ Itemid $=76$ accessed on 12/11/2012.

[19] Ryan, R. (2001), Master Concept or Defensive Rh0toric: Australian VET policy against past practice and current international principles of lifelong learning. International Education Journal 2 (3), 133-147.

[20] UNESCO and ILO. (2002), Technical and Vocational Education and Training for the Twenty-First Century. UNESCO and ILO Recommendation. 